\title{
Teaching Languages to Deaf Students in Brazil at the Intersection of Discourses
}

\author{
Ensino de línguas para alunos surdos no \\ Brasil na interseção dos discursos
}

Larissa Bassi Piconi*

Universidade Tecnológica Federal do Paraná

Londrina - Paraná / Brasil

\begin{abstract}
This work aims to discuss multilingual issues involving teaching languages to the deaf in Brazilian schools. For this purpose, it proposes an analysis of a set of materials produced by the Brazilian Ministry of Education aimed at situating means through which to act, represent and identify the deaf, as well as practices of teaching Brazilian Sign Language and Portuguese to this social group, based on the Critical Discourse Analysis (CDA) framework. Investigating discursive practices on this issue is important, as it allows one to identify the changes in the maintenance/transformation of recognition issues regarding the deaf in the Brazilian context. This analysis illustrates a multiplicity of voices that work to establish controversy upon evoking different meanings and a power struggle regarding the preservation of rules that currently guide the processes of language teaching for the deaf in an inclusive perspective.
\end{abstract}

KEYWORDS: Language Teaching, Deaf, Critical Discourse Analysis.

RESUMO: Este trabalho objetiva discutir questôes acerca do ensino de línguas para surdos nas escolas brasileiras e, para tanto, propōe analisar um material produzido pelo Ministério da Educação a fim de situar modos de agir, representar e identificar os surdos e as práticas de ensino da Língua de Sinais Brasileira e a Língua Portuguesa para esse grupo a partir do referencial da Análise do Discurso Crítica. Investigar práticas discursivas sobre essa questão é importante, pois possibilita identificar movimentos de manutenção/transformação das questões de reconhecimento dos surdos no contexto brasileiro. A análise aponta para uma multiplicidade de vozes que operam para o estabelecimento da polêmica ao evocar diferentes sentidos e uma luta pelo poder em relação à preservação das regras que atualmente orientam os processos de ensino de línguas para os surdo em uma perspectiva inclusiva.

PALAVRAS-CHAVE: Ensino de línguas, Surdos, Análise do Discurso Crítica.

*larypiconi@utfpr.edu.br 


\section{Introduction}

The debate on deaf education in Brazil has been broadened over the past two decades and has called attention to linguistic and cultural issues regarding the recognition of the deaf in Brazilian contexts. The role of Sign Languages and Portuguese (the official language of the country) plays a key role in this debate. Language issues are at the core of initiatives that aim to expand the participation of deaf people and their recognition within this social context.

In 2002, Brazilian Federal Law 10.436/2002 (Libras Law), which established Brazilian Sign Language as an official language in Brazil, was put into effect. The instituting of a language policy regarding Brazilian Sign Language was the result of actions and requests by social movements for the deaf which have modified their means of political representation and have created ways for communicating their feelings about being deaf and their demands for recognition in recent years. This process was facilitated by research that has reified the linguistic status of Brazilian Sign Language as well as by cultural studies that have pinpointed questions of identity and culture among deaf people in such a way as to comprehend this social group beyond the deficiency paradigm. The Libras Law was later regulated by Decree 5.626/2005, which regulated specific processes regarding this law's implementation in different contexts, including the field of education.

During the same period, in the early 2000`s, the Brazilian government developed a program aimed at consolidating the Special Education Policy, which assured the enrollment of deaf students in mainstream schools. Deaf students began to attend mainstream schools across the country and school communities began to face a multilingual situation where Portuguese and Sign Languages shared, or were supposed to share, the same space in schools.

These processes are therefore impacted by discursive practices that produce and reproduce meanings, as well as evoke different representations of the deaf, sign languages, cultures, and identities. They call upon value systems and forms of life that are considered desirable and authentic in a country. This is true because the choice of an official language or a decision about the curriculum of public schools expresses ethical political decisions and mobilizes issues concerning a collective identity of citizens that can spark cultural battles in which disrespected minorities struggle against an insensitive majority culture (HABERMAS, 1994). 
One of the cultural battles that the recognition of Brazilian Sign Language as a national language sparks lies in its relation to the official language of Brazil, Portuguese, and the representations of Brazil as a monolingual country (CAVALCANTI, 1999; FARACO, 2002; OLIVEIRA, 2002; OLIVEIRA, 2007; TABLES, 2012). Portuguese is predominantly represented as the only language spoken in Brazil, presenting itself as a shared element among all Brazilians and therefore an essential part of an imagined Brazilian national identity. This representation in turn favors the exclusion of other language communities, since, in a nation imagined to be cohesive and monolingual, those who communicate through languages other than the official language are deprived of access to membership in this (whether real or imagined) community (BLACKLEDGE, 2005).

Furthermore, Brazilian Sign Language has undergone a trajectory of cultural battles that have served to work for and against both its legitimization as a language, as well as its right to move freely and unrestrictedly within all spaces of social life. The acquisition and use of Sign Languages was avoided for many years in deaf children's education, as it was considered an obstacle to learning how to speak the official language of their country. Still, different representations for sign language share spaces in public spheres and its recognition as a proper language coexist with ideas that do not recognize its language status.

In this context, this research will focus on language issues in the dynamics involving social relations of power embedded in institutional practices of teaching Brazilian Sign Language and Portuguese to deaf students and how power operates for discrimination and non-recognition among groups. It is thus my assumption that "language is a fundamentally social phenomenon, and linguistic practices are not separate from the beliefs and attitudes relating to languages in societies. Nor are language ideologies always fixed or straightforward (CREESE; BLACKLEDGE, 2011, p. 1197). Moreover, language is closely related to power relations because "it is usually in language that discriminatory practices are enacted, in language that unequal relations of power are constituted and reproduced, and in language that asymmetries may be challenged and transformed" (BLACKLEDGE, 2005, p. 5).

Considering that discourse is one important component of these political discussions and a means by which cultural battles are set and dissolved, this work aims to identify how orders of discourse shape 
institutional practices of teaching languages to deaf students in public schools. Therefore, I propose an analysis of a document published in 2007 by the Brazilian Government with the purpose of preparing public school teachers and staff to provide deaf students with Specialized Educational Support Services in public schools. When it comes to deaf education, Specialized Educational Support services is a program in the inclusive schools that seeks to provide deaf students with their linguistic needs, it is a space where deaf students should learn Brazilian Sign Language and Portuguese as a second language. The critical discourse analysis (CDA) applied to this document can contribute to the understanding of ideological relations that Portuguese and Brazilian Sign Language evoke in perspectives for deaf literacy. By analyzing this material, it is my intention to trace ways by which government policies have been representing, acting, and identifying the deaf and circumstances of bilingualism in schools.

This analysis is part of a broader research project that investigates how discursive practices uncover cultural battles involving linguistic and educational bias in deaf people's education. The major purpose of this project is sustained by the assumption that analyzing how discourse operates in texts can potentially reveal ways through which language teaching is associated with issues of the recognition or misrecognition of the deaf in Brazilian society. This analysis will eventually be linked to the analysis of other texts produced by different instances of social life on the practice of teaching language to deaf communities. The analysis of these texts is aimed at tracing how not only particular events, but also a series of circumstantially related events, work toward the maintenance and transformation of practices related to the recognition of the deaf in society and the role of language education in the process. The importance of such an analysis lies in the fact that these texts can reveal the configuration of discourse in these social practices and the changes in time and context that can contribute to the description, interpretation, and explanation of ways in which orders of discourse accompany the processes of teaching and learning these languages.

\section{Some assumptions on language and society}

This work assumes some of my own particular ways of understanding the social world that I bring with me throughout the elaboration of this research and calls upon some concepts that frame its development. Central to this work is the recognition that social changes are greatly constituted by 
changes in language practices; therefore, movements of social and cultural change can be identified in language (FAIRCLOUGH, 1992). Thus, I have chosen to use the lenses provided by CDA to observe the relations between language and society from the vantage point of the description, interpretation, and explanation of these relations in discursive practices.

The importance of investigating discourses lies in the fact that:

Discourse contributes to the constitution of all those dimensions of social structure which directly or indirectly shape and constrain it: its own norms and conventions, as well as the relations, identities and institutions which lie behind them. Discourse is a practice not just of representing the world, but of signifying the world, constituting and constructing the world in meaning (FAIRCLOUGH, 1992, p. 64).

This work recognizes that the dynamics between language (and other semiotic modes) and society are established through a complex chain of discourses and, therefore, analyzing texts/semiotic products produced in different spheres makes it possible to visualize ways through which discourses are recontextualized, transformed, enhanced, and deleted, as well as how they gain authority and legitimacy in less flexible and negotiable contexts of social life (BLACKLEDGE, 2005).

In this perspective, texts are considered important means by which people act, interact, and build relations of power, identity, and knowledge. Texts are fundamental tools for the interaction of agents in broader, more diverse, and complex forms of social practices. They therefore allow us to see discursive practices at work toward the maintenance/transformation of social relations, identities, and ways of representing the world. The production of texts is constrained by various orders in a dynamic relation among events, social practices, and social structure.

Social structure refers to a more abstract and inflexible level of the social world that defines sets of possibilities for the production of more concrete events, such as texts. Examples of this social structure are the systems of languages themselves, which delimit the possibilities of combining linguistic elements of a text, as well as economic and political structures of society, which affect the configuration of more concrete events of the social world.

Social structures and social events are connected by means of social practices. Social practices refer to the "point of connection between abstract structures, their mechanisms, and concrete events" (RAMALHO; 
RESENDE, 2011, p. 15), which are established in the habitual ways people make use of material and symbolic resources at a given time and place in order to act and interact in the world. Examples of social practices are practices of language teaching in schools for the deaf, as well as any other social practices that involve relationships, action, interaction among people, material resources, technologies, and discourse (FAIRCLOUGH, 2003).

Discourse is understood as the semiotic component of social practices through which a dialectic relationship between language/semiosis and other non-discursive social practices are established. Thus, CDA aims to examine the relationship between discourse and other elements of the social world, and analyze the relationships between the linguistic/semiotic elements of social events in relation to the linguistic/semiotic facets of social structures and social practices (FAIRCLOUGH, 2005). The CDA approach makes use of texts as the main (but not the only) empirical material of analysis from which an investigation of these relations in language as a system, text, and order of discourse is established. This is possible because of the focus on the level of orders of discourse, which allows the analysis to transit between these three levels of language (RAMALHO; RESENDE, 2011).

Order of discourse is understood as the semiotic aspect of networks of social practices. This concept assumes that social practices are never isolated, but rather they are located in a network of practices that operate to restrict its properties. This network of practices produces social effects that are results of social power relations that drive movements of displacement and resistance to power. A network of practices is constituted in parts of language elements (orders of discourse) that "select certain possibilities defined by languages and exclude others - they control linguistic variability for particular areas of social life" (FAIRCLOUGH, 2003, p. 24). The elements of this order of discourse include discourses, genres, and styles that are related, respectively, to the ways of representing, acting, and being manifested in language. Fairclough (1992) states that, at the same time texts represent aspects of the world (representation), they also build social relationships among the participants, pervaded by attitudes, intentions, and multiple values (action). Texts also establish the relation between text and situational and contextual aspects by means of the junction of elements that create the effect of cohesion and coherence (style).

Thus, CDA investigates the location of the discourse and its relation to the network of orders of discourse (structural perspective) and how this 
articulatory work is done in the text (interactional perspective) through the use of linguistic resources in the textual production of discourse. This process is constrained by many factors, given that "the relationship between discourse and social network orders of discourse depends upon the nature of social practice and conjuncture of the social practices it is located within, and how it figures within them" (CHOULIARAKI; FAIRCLOUGH, 1999, p.63).

The text analyzed in this work is part of a social practice of preparing teachers and school staff to teach deaf students in schools and is located in a network of teaching practices related to the educational and language policies to deaf people in Brazil. The text works in such a way as to regulate the practices of teaching the written form of Portuguese and Brazilian Sign Language in the context of Specialized Educational Support Services in public schools in Brazil and inevitably "control the selection of certain structural possibilities and the exclusion of others, and the retention of these selections over time in particular areas of social life" (FAIRCLOUGH, 2011, p. 120).

This movement is noticed in the ways the text (inter)acts through language. The document interacts by means of the genre 'textbook' and has an important function in sustaining structural relations on different scales, in this case, between the policies developed by the government and its implementation in public schools. Preparing teachers to work in certain ways functions as an important bridge to connect the policy and its implementation in the classroom context. Second, the textbook works as part of this social practice by producing and reproducing representations for the deaf and the practices of teaching languages to this social group. These representations draw on different discourses, producing different perspectives and positions to the same area of social life. Finally, the relations between this text and macro social structures are also established in the ways this social practice constitutes particular ways of being, particular social identities that evoke particular behaviors about what it means to be an official authority, a researcher, a teacher, or a student, for example.

The effects of these orders of discourse on the current practices of teaching deaf students in public schools are not predictable and they are not established in a regular cause-effect pattern. The impact of this text on ways of representing, interacting, and being in regards to deaf education and the practices of teaching languages to deaf students in public schools depends on various contextual factors. However, because many other factors in the 
context determine whether or not particular texts as parts of particular events actually produce such effects, this finding can lead to a particular text producing a variety of effects (FAIRCLOUGH, 2011).

The present work focuses mainly on a major casual effect of texts and the effects of texts in inculcating and sustaining ideologies. Ideologies are understood as:

Representation of aspects of the world that can be shown to contribute to establishing and maintaining relations of power, domination, and exploitation - primarily because such representations can be enacted in ways of interacting socially and inculcated in ways of being in people's identities (FAIRCLOUGH, 2011, p. 123)

Therefore, the ideological work embedded in discursive practices is a means by which movements of recognition and non-recognition come into being. Particular values, practices, and beliefs regarding languages and their users are produced and reproduced in texts. These may well contribute to the maintenance of certain ways through which power works toward the production and reproduction of social difference and discrimination.

\section{The text and the Context}

The text "Educação Escolar Inclusiva para Pessoas com Surdez" (DAMÁZIO, 2007) is part of a textbook produced by the Department of Special Education ${ }^{1}$, under the Ministry of Education, and integrates a continuing teacher education program aimed at preparing teachers to work for the Specialized Educational Support Service in public schools as part of the Special Education Policy consolidated by the Brazilian government through Decree 3298/99 ${ }^{2}$ and Resolution CNE/CEB 02/20013, that made the enrollment of students with special needs in public schools compulsory.

\footnotetext{
${ }^{1}$ The Department of Special Education was extinguished according to Decree 7.480 of May 16, 2011; the duties and programs attributed to that department are now under the responsibility of the Department of Continuing Education, Literacy, Diversity, and Inclusion (SECADI).

${ }^{2}$ This document provides the guidelines for the National Policy for the Integration of People with Disabilities; it consolidates protection standards and provides other measures.

3 This document establishes the National Guidelines for Special Education in Elementary and Secondary Education.
} 
According to this resolution, "education systems must enroll all students, with schools being held responsible for organizing themselves to care for learners with special educational needs, ensuring the necessary conditions for an education of quality for all”4 (BRASIL, 2001).

The Inclusive Education Policy in Brazil was a response to particular agreements made between the Brazilian government and international organizations in the 90s, which established specific guidelines for the organization of developing countries in face of the political and economic changes that had occurred since the economic crisis the 70s (PICONI, 2009). To include the developing countries in the global restructuring mode of production (globalization), educational systems received a privileged focus, since schools are normally considered institutions conducive to the preparation of people for an 'ideal' society. The Inclusive Education Policy fits into this context for public schools "represent the most effective means for combating discriminatory attitudes, creating welcoming communities, building an inclusive society and providing education for all" (BRASIL, 2004, p. 16).

The Brazilian Government has been implementing the "Inclusive Education Program: The Right to Diversity" since 2003 in an attempt to shape the inclusion of students with special needs in Brazilian public schools. Training administrators and educators and providing schools with equipment, furniture, and teaching materials were part of this program and were aimed at supporting the specialized educational services in public schools. In the Brazilian educational system, most schools divide their academic day into three sessions: mornings, afternoons, and evenings, and students attend only one session per school day. The Inclusive Education Program aimed to guarantee that students with special needs attended one session in mainstream classes and were offered a Specialized Educational Support Service in another session at the same schools so as to support them in their special needs.

The analyzed textbook integrates this program, which can be found in a network of practices of the organization and implementation of the Specialized Educational Support Service to students with special needs who attend public schools throughout the country. In 2007, the Department of Special Education and the Department of Distance Education, linked to

\footnotetext{
${ }^{4}$ Translated by the author.
} 
the Ministry of Education, in partnership with the Federal University of Ceará, organized a distance-learning teacher education course with the goal of preparing 1,044 public school teachers to work at Specialized Educational Support Service in schools.

By the time this textbook was produced, different perspectives regarding deaf education were already in dispute. One of the main expectations by the representative associations of deaf communities since the recognition of Brazilian Sign Language in Brazil was the establishment of bilingual schools for deaf students where Brazilian Sign Language would be the language of instruction and Portuguese would be taught as a second language. However, this demand conflicted with the Inclusive Education Policy program and the understanding that deaf students should attend mainstream schools and have access to a common curriculum with other non-deaf students. A reconciling view on these perspectives was aimed to be achieved by establishing the space of the Specialized Educational Support Service as that in which a bilingual education for deaf students should occur (BRASIL, 2007).

However, these different perspectives to deaf education are guided by different meanings for deafness and different ways to conceive of language teaching in deaf education. To see how these differences are negotiated in the textbook, I will highlight the features of intertextuality and interdiscursivity mobilized in the document so as to identify ways of representing, acting, and identifying the deaf and language teaching for this social group and how differences are negotiated.

\section{Inclusive School Education for People with Deafness: Textu- ring the Analysis}

This section begins with a brief description of the analytical tools employed in the approach to the data and present some initial considerations on the analysis. It then moves toward a more detailed analysis of the article "Educação Escolar Inclusiva para Pessoas com Surdez" (DAMÁZIO, 2007) to reveal the ways by which this document represents, acts, and identifies the deaf and circumstances of bilingualism in schools, as well as how different meanings and discourses operate within this text. 


\section{Initial Considerations on the Analysis}

The text under analysis integrates the textbook entitled Atendimento Educacional Especializado (AEE) - Pessoa com Surdez (Special Education Service - Person with Deafness, my translation), which is available on the Department of Continuing Education, Literacy, Diversity, and Inclusion's website. The textbook consists of five chapters, each containing an article and an indication of references under the heading of "to learn more". The article "Educação Escolar Inclusiva para Pessoas com Surdez" (DAMÁZIO, 2007 ) is part of Chapter 1, of the same name, and introduces the textbook.

The article was originally written in Portuguese and, to provide the readers with the description and explanation of my interpretation of this text, excerpts from the article translated into English will be quoted. Despite the attempt to keep the text as close as possible to its original content, I recognize that the translating process itself inevitably changes meanings and ways of signifying. To compensate for this drawback, excerpts will be accompanied by their original version in Portuguese in the footnotes.

Two main analytical tools guided the analysis of the data: intertextuality and interdiscursivity. Intertextuality refers to mechanisms that articulate the text with other voices external to it. Recognizing the ideas of Bakhtin (2002) about dialogical texts, these mechanisms highlight the means through which the text responds and anticipates responses to other texts, thus participating in a dialogical chain of articulation of different voices (polyphony), which are internally mobilized within it. Intertextuality can be marked in the text, as in the use of direct and indirect quotations and/or can appear implicitly in assumptions that report on what has been said or written by someone at a given time and place in a vague and unmarked reference and refer to meanings taken for granted by the author of the text as given, established, and commonly shared meanings.

The analysis of interdiscursivity relates to the process of identification of different discourses, different ways of representing the social world, and examines how these representations are articulated in the text. Therefore, interdiscursivity can be accomplished through the identification of areas of social life that are represented in the text by locating its main themes. In addition, interdiscursivity can be analyzed by means of the identification of how vocabulary and lexicon are articulated in the text, given that different ways of naming the world can reveal different ways of representing it.

By analyzing the features of intertextuality and interdiscursivity in the text, I intend to identify how different voices are brought together in the text 
and how different meanings are negotiated. Fairclough (2003, p. 41/42) differentiates five scenarios concerning the orientation to difference in texts:

a) an openness to, acceptance of, recognition of difference; an exploration of difference, as in 'dialog' in the richest sense of the term;

b) an accentuation of difference, conflict, controversy, a struggle over meaning, norms, power;

c) an attempt to resolve or overcome difference;

d) a bracketing of difference, a focus on commonality, solidarity;

e) consensus, a normalization and acceptance of differences of power which bracket or suppress differences in meanings and norms.

The orientation to difference in a text may well reveal movements toward the emergence of new meanings and norms in social interactions and the possibilities for different relations of power and possibilities of intervention in a series of events so as to alter their course. Concomitantly, they can reveal movements that prevent new meanings from emerging and can sustain norms, rules, and the way power operates in this process.

\section{Representing the deaf: differences in discourse}

The chapter "Educação Escolar Inclusiva para Pessoas com Surdez" reveals different ways of representing 'people with deafness' and language teaching in deaf education. It is important to mention that the author chooses to use the term 'people with deafness' instead of 'the deaf'. The term 'people with deafness' is defined in a footnote as "a way to make reference to people with a hearing impairment, regardless of the degree of their sensory loss"s. This definition is anchored exclusively on biological features of being deaf and excludes cultural and linguistic elements that some deaf people usually fight to be recognized for.

Some assumptions are mobilized in the characterization of 'people with deafness'. These assumptions reveal preconceived perceptions on the existence of certain realities (marked in the use of definite articles) and

\footnotetext{
${ }^{5}$ Doravante deve-se entender o uso do termo pessoa com surdez como uma forma de nos reportamos a pessoas com uma deficiência auditiva, independente do grau da sua perda sensorial.
} 
assume values about what is considered desirable or undesirable in relation to the stated assumptions.

Studying schooling of people with deafness refers to not only issues concerning their limits and possibilities, but also to the existing prejudices in society's attitudes toward them.

People with deafness face innumerable barriers to participate in school education due to their hearing loss and to the ways through which the curriculum is structured in schools. Many students with deafness may be harmed by the lack of appropriate stimuli for their cognitive, socioaffective, linguistic, and political-cultural potential. ${ }^{6}$ (DAMÁZIO, 2007, p. 13)

In these two introductory paragraphs, I highlight the following assumptions that evoke ways of representing the deaf:

\section{TABLE 1}

Assumptions evoking representations of deaf people

\begin{tabular}{|l|l|}
\hline Assumptions & Linguistic Evidence \\
\hline $\begin{array}{l}\text { Deaf people have limits } \\
\text { and possibilities }\end{array}$ & $\begin{array}{l}\text { Assumption identified in the use of possessive pronoun } \\
\text { 'their' at "Studying the schooling of people with deafness } \\
\text { reports to not only issues concerning their limits and } \\
\text { possibilities (...)". }\end{array}$ \\
\hline $\begin{array}{l}\text { There is prejudice regarding } \\
\text { the attitudes formulated by } \\
\text { society towards people with } \\
\text { deafness }\end{array}$ & $\begin{array}{l}\text { Assumption identified in the use of the definite article in } \\
\text { "but also to the existing prejudices in society's attitudes } \\
\text { toward them"). }\end{array}$ \\
\hline
\end{tabular}

\footnotetext{
${ }^{6}$ Estudar a educação escolar das pessoas com surdez nos reporta não só a questões referentes aos seus limites e possibilidades, como também aos preconceitos existentes nas atitudes da sociedade para com elas. (...) As pessoas com surdez enfrentam inúmeros entraves para participar da educação escolar, decorrentes da perda da audição e da forma como se estruturam as propostas educacionais das escolas. Muitos alunos com surdez podem ser prejudicados pela falta de estímulos adequados ao seu potencial cognitivo, sócio-afetivo, linguístico e político-cultural e ter perdas consideráveis no desenvolvimento da aprendizagem.
} 


\begin{tabular}{|l|l|}
\hline $\begin{array}{l}\text { There is a lack of appropriate } \\
\text { stimuli for deaf people`s } \\
\text { learning development }\end{array}$ & $\begin{array}{l}\text { Assumption identified in the use of definite article in } \\
\text { "Many students with deafness may be harmed by the lack } \\
\text { of appropriate stimuli". }\end{array}$ \\
\hline Deaf people have potential & $\begin{array}{l}\text { Assumption identified in the use of possessive pronoun } \\
\text { "their cognitive, socio-affective, linguistic, and political- } \\
\text { cultural potential". }\end{array}$ \\
\hline
\end{tabular}

These assumptions, in addition to the semantic loads of the lexicons of 'limits', 'prejudice', 'lack', 'harm', and 'loss' reveal representations of deaf people as fragile and vulnerable people. These representations work in such a way as to sustain the argument that school education should foster the development of people with the 'potential' and 'possibilities' for deafness. This movement is also noticed in the excerpts taken from the third and fifth paragraphs.

Studies carried out by several authors and researchers during the last decade of the 20th century and during the early years of the 21 st century provide contributions to education of students with deafness in regular public schools, emphasizing the appreciation of differences in social life and the recognition of every human being's potential. (...)

Thus, how would it be to act with students with deafness in a common public school that recognizes and appreciates the differences? What sort of curricular and pedagogical processes need to be created to comply with this difference, considering a school that is open for all and, therefore, truly inclusive? ${ }^{7}$ (DAMÁZIO, 2007, p. 13)

The terms "common public school", "school that is open for all", "appreciates the differences", "inclusive school" evoke the inclusive education discourse and juxtapose the text with the inclusive educational policies introduced in Brazil in the

\footnotetext{
${ }^{7}$ Estudos realizados na última década do século XX e início do século XXI, por diversos autores e pesquisadores oferecem contribuições à educação de alunos com surdez na escola comum ressaltando a valorização das diferenças no convívio social e o reconhecimento do potencial de cada ser humano. (...) Sendo assim como seria atuar com alunos com surdez, em uma escola comum que reconhece e valoriza as diferenças? Que processos curriculares e pedagógicos precisam ser criados para atender a essa diferença, considerando a escola aberta para todos e, portanto, verdadeiramente inclusiva?
} 
90s, as briefly presented earlier. The term 'difference' is accompanied by the words 'appreciation' and 'appreciate' and evokes a particular way of representing society and schools as spaces where differences are wanted and desired. This representation in turn exacerbates issues related to discriminatory processes and power relations embedded when dealing with these differences.

By bringing these representations to the text, the article acts in such a way as to connect a more micro and local strata of social practices, such as the practice of preparing teachers to work at the Specialized Educational Support Services in schools, to a more macro and global strata, that is, to the inclusive education policy and the system of values that regulate this policy.

The article anticipates answers to possible criticisms and questionings to the proposed ideas and evokes a struggle for meanings over norms and power between the different ways of representing the deaf and their education, which coexist in society, as can be seen in the following excerpt:

(...) Those who defend the deaf culture, identity, and community are rooted in the discourse of differences, claiming that they need to be understood as regards their own specificities, however, one can fall into the trap of difference, as defined by Pierucci (1999), that in the name of difference one can also segregate. ${ }^{8}$ (DAMÁZIO, 2007, p. 14)

In this passage, another voice is brought to the text, one that mobilizes a different representation of 'deaf people' and 'difference' based on the assumption of the existence of a deaf culture, identity, and community, as well as a discourse of differences ("Those who defend the deaf culture, identity, and community find their roots in the discourse of difference). However, the author maintains a certain distance from the stated ideas. The pronoun 'those' establishes a separation between I versus them. Still, these representations are portrayed as dubious by the use of the word 'claim' and the metaphor 'fall into the trap' in "claiming that they need to be understood as regards their own specificities, however, one can fall into the trap of difference". This suspicion is further reified by an indirect quotation that

\footnotetext{
${ }^{8}$ Àqueles (sic) que defendem a cultura, a identidade e a comunidade surda apóiam-se no discurso das diferenças, alegando que elas precisam ser compreendidas nas suas especificidades, porém, pode-se cair na cilada da diferença, como refere Pierucci (1999), que em nome da diferença, pode-se também segregar.
} 
gives authority to what is being said at the same time that it minimizes the responsibility of the author for what has been stated.

The 'discourse of difference' is portrayed in a distinct way as compared to the "appreciation of difference", which was presented in the previously discussed excerpt. The 'discourse of difference' is here associated with the need to understand the deaf people's specificities. These two different positions to issues of recognition of 'difference' are linked to different discourses regarding the education of deaf people mobilized in the text: the inclusive education discourse and the bilingual school discourse.

\section{Teaching languages and bilingualism in deaf education: difference in discourse}

Different ways of representing the deaf evoke particular ways of understanding the role of Portuguese and Brazilian Sign Language in deaf education. I previously argued that this document reaffirms the inclusive policy and its values. To do so, the text values certain ways to represent the deaf, anchored on biological features and mitigating perspectives that acknowledge the existence of a deaf culture and identity. In the following excerpts, I show how the text operates to mitigate the role of Sign Language in deaf education.

Since Brazilian Sign Language was recognized as an official language in Brazil, voices from the deaf social movement, as well as from academia, have been increasingly pinpointing the central role Brazilian Sign Language plays in deaf children's development. Some of these voices have been arguing for the need for bilingual schools for deaf students. A bilingual school would be that in which Brazilian Sign Language is the language of instruction and Portuguese is taught as a second language. Among other issues, this demand is based on the perception that sign languages are the natural language for the deaf and that the cognitive, affective, social, cultural, and academic success on the part of the deaf depends on the acquisition of sign languages (FENEIS $\left.{ }^{9}, 2013\right)$.

However, the bilingual discourse complicates the inclusive policy discourse. This is so because inclusive education is grounded on the principle

\footnotetext{
${ }^{9}$ Feneis is as a representative organization of deaf communities in Brazil that unites approximately 120 member organizations (Associations of the Deaf, Associations of Parents and Friends of Deaf Schools and Specialized Clinics in serving deaf people, among others). This organization is one of the most influential organization of deaf social movement in Brazil that defends the interests and needs of deaf communities in the country.
} 
of one's right to a common curriculum and a common context. By contrast, the bilingual perspective is not anchored on what is common, but rather on what it is particular in relation to deaf students and their language.

The analyzed document, in an attempt to reify the inclusive discourse, evokes voices from the bilingual perspective in such a way as to challenge them. This movement is identified in the following fragments.

\section{TABLE 2}

Intertextuality - evidence of non-attributed voices

\begin{tabular}{|c|c|}
\hline Fragment 1 & $\begin{array}{l}\text { (...) the simple adoption of this language (Sign Language) is not enough } \\
\text { for the school education of students with deafness. }{ }^{10}\end{array}$ \\
\hline Fragment 2 & $\begin{array}{l}\text { More than the use of a language, students with deafness need stimulating } \\
\text { educational environments }(\ldots)^{11}\end{array}$ \\
\hline Fragment 3 & $\begin{array}{l}\text { If only the use of a language was enough to learn, hearing people would } \\
\text { not have problems with school performance }(\ldots)^{12}\end{array}$ \\
\hline Fragment 4 & $\begin{array}{l}\text { The acquisition of sign language, in fact, is no guarantee of meaningful } \\
\text { learning }(\ldots)^{13}\end{array}$ \\
\hline Fragment 5 & $\begin{array}{l}\text { (...) We must overcome the view that reduces the problems of schooling } \\
\text { for people with deafness to the use of this or that language }(. .)^{14}\end{array}$ \\
\hline
\end{tabular}

These fragments evoke voices produced in outside instances that are not designated in the text that mobilize the following meanings: the adoption of sign language is enough to educate the student with deafness (fragment 1, by means of denial); students with deafness need the use of a language (fragment 2, by the use of 'more than'), the use of a language is

\footnotetext{
${ }^{10}$ Fragmento 1: (...) a simples adoção dessa língua (Língua de Sinais) não é suficiente para escolarizar o aluno com surdez.

${ }^{11}$ Fragmento 2: Mais do que a utilização de uma língua, os alunos com surdez precisam de ambientes educacionais estimuladores (...)

${ }^{12}$ Fragmento 3: Se somente o uso de uma língua bastasse para aprender, as pessoas ouvintes não teriam problemas de aproveitamento escolar (...)

${ }^{13}$ Fragmento 4: A aquisição da Língua de Sinais, de fato, não é garantia de uma aprendizagem significativa (...)

${ }^{14}$ Fragmento 5: (...)É preciso ultrapassar a visão que reduz os problemas de escolarização das pessoas com surdez ao uso desta ou daquela língua (...)
} 
not enough for learning (fragment 3, by means of the conditional 'if'), that sign language is a guarantee of meaningful learning (fragment 4 , by means of denial), that the problems of the school education of people with deafness are related to the use of languages (fragment 5 , by means of an assumption of an existing view).

A controversy is established in the document by bringing voices from a different perspective to deaf education into the text and, as they are brought up, they are rejected. This controversial relation is related to the interdiscursive dynamic of the text, which calls into question the Inclusive Education Discourse and the Bilingual School Discourse. In this process, the text operates to minimize discourses on deaf education that somehow threaten the inclusive education policy by establishing a controversy that works to reassert the inclusive education approach as the valuable option to deaf education. Linguistic issues are represented as minor and multicultural issues; identity and linguistic diversity are mitigated in deaf education.

\section{Voices and levels of commitment}

In the previous sections, I showed how different perspectives were articulated in the text in order to build representations of the deaf and to establish a controversy regarding the role language plays in deaf education. I then moved on to discuss how different voices and perspectives were mobilized in order to legitimatize the meanings produced and the controversy established.

Indirect quotations are predominantly employed in the organization of the text. Statements were taken from their original contexts and incorporated in the article so as to serve as arguments to confer authority and legitimacy to particular propositions. In the process of recontextualization of these voices, the author indicates a high affinity to these statements, often making it difficult to differentiate exact whose voice is whose - the quoted author's or the text's author's voice, as can be seen in the following excerpt:

(...) The acquisition of sign language, in fact, is no guarantee of meaningful learning, as Poker showed (2001), when he worked with six students with profound hearing loss who were enrolled in the first stage of elementary school, aged between eight and nine months and 11 years and nine months, investigating, by means of educational interventions, the symbolic exchanges and the cognitive development of these students. ${ }^{15}$ (DAMÁZIO, 2007, p. 15) 
In "the acquisition of sign language, in fact, is no guarantee of meaningful learning," the author's and Poker's (2001) voices merge in such a way that it becomes impossible to distinguish when one voice begins and the other ends, suggesting a high affiliation by the author with the represented discourse. Moreover, the use of the expression 'in fact' sustains a high degree of certainty in relation to what was stated. At the same time these voices merge, a relative distance is set in "as Poker showed (2001)" in such a way as to reduce the author's responsibility concerning the stated proposition by assigning it to someone else. The identification of Poker as a researcher legitimatizes the idea proposed by the authority that comes from this identity.

There is a high commitment by the author to certain 'truths'. The text is structured predominantly by the use of non modalized categorical statements that set a relation between "what it is" and "what it is not", and by deontic modalities, which are elements that express prohibition, obligation, permission, such as the use of the word 'must'. These elements limit the possibilities for other meanings to emerge and reflect a hegemonic struggle aimed at sustaining power relations, as exemplified below:

(...) Public schools must ensure a school education (to students with deafness) in one session and provide them with a Specialized Educational Support Services in another in such a way as to contemplate the teaching of Brazilian Sign Language, teaching in Brazilian Sign Language, and the teaching of the Portuguese language. ${ }^{16}$ (DAMÁZIO, 2007, p. 15)

The word 'must' is employed in "Public schools must ensure a school education (to students with deafness)" in an attempt to once again sustain the Inclusive Education Policies. Public schools (as opposed to bilingual

\footnotetext{
${ }^{15}$ A aquisição da Língua de Sinais, de fato, não é garantia de uma aprendizagem significativa, como mostrou Poker (2001), quando trabalhou com seis alunos com surdez profunda que se encontravam matriculados na primeira etapa do Ensino Fundamental, com idade entre oito anos e nove meses e 11 anos e nove meses, investigando, por meio de intervençôes educacionais, as trocas simbólicas e o desenvolvimento cognitivo desses alunos.

${ }^{16}$ (...) a escola comum deve viabilizar sua escolarização (dos alunos com surdez) em um turno e o Atendimento Educacional Especializado em outro, contemplando o ensino de Libras, o ensino em Libras e o ensino da Língua Portuguesa.
} 
schools) are highlighted as the space in which deaf education should occur, while the Specialized Educational Support Services is designated as the space designated for language teaching.

These elements point to the fact that the multiplicity of voices in the article did not favor the establishment of dialog and the negotiation of differences in meanings, but they did serve to accentuate conflicts and a controversy embedded within different perspectives of deaf education. They also served to sustain a struggle for the preservation of the rules that currently govern this process.

\section{Final Remarks}

This article aimed to examine a sample of data that integrates a broad research project in order to present CDA as a potential framework for the investigation of ways of representing, identifying, and acting with regards to language issues in deaf education and how these processes are linked to issues of the maintenance/transformation of the dynamics of the recognition/ misrecognition of the deaf in the Brazilian context.

By analyzing the article, "Educação Escolar Inclusiva para Pessoas com Surdez ", I sought to identify how a textbook produced by the Department of Special Education, linked to the Brazilian Ministry of Education, acts in relation to the deaf and the practices of language teaching, anchored on the analytical categories of interdiscursivity and intertextuality.

The analysis showed ways in which the text served to sustain the institutional structure of the inclusive policy by articulating different voices that worked toward the establishment of a controversy and a conflict between the different modes used to represent the deaf and the role of languages in their education.

This text does not go beyond confrontation and controversy, which minimizes the potential for an effective dialog in the public sphere concerning the politics of identity, which, according to Habermas (2005), is essential for the transformation of interpersonal relationships and, ultimately, for the mutual recognition of the equal status of all members in a multicultural society. 


\section{References}

BAKHTIN, M. Marxismo e filosofia da linguagem. São Paulo: Hucitec, 1929/2002. BRASIL. National Board of Education. Chamber of Basic Education. Resolution CNE/CEB 2/2001, ratified on September 14, 2001. Sets forth national guidelines regarding Special Education in basic public school education. Available at: <http:// portal.mec.gov.br/cne/arquivos/pdf/CEB0201.pdf>. Retrieved May 30, 2013.

BRASIL. Ministry of Education. Department of Special Education. Brazilian Law 10.436, ratified on April 24, 2002. Report on Brazilian Sign Language (Libras) and other such measures. Available at: <http://www.planalto.gov.br/ccivil_03/leis/2002/ 110436.htm>. Retrieved May 30, 2013.

BRASIL. Ministry of Education. Department of Special Education. Inclusive Education: the philosophical fundamentals. Brasília: SEESP/MEC, 2004. Available at: <http://portal.mec.gov.br/seesp/arquivos/pdf/fundamentacaofilosofica.pdf>. Retrieved May 30, 2013.

BRASIL. Ministry of Education. Department of Special Education. Decree 5.626, ratified on December 22, 2005. Provides regulations for Law 10.436, ratified on Apriol 24, 2002. Available at: <http://www.planalto.gov.br/ccivil_03/_ato20042006/2005/decreto/d5626.htm>. Retrieved May 30, 2013.

BRASIL. Ministry of Education. Department of Special Education. National Policy on Special Education from the Perspective of Inclusive Education. Brasília: SEESP/ MEC, 2007. Available at: <http://portal.mec.gov.br/seesp/arquivos/pdf/politica. pdf $>$. Retrieved April 12, 2012.

BLACKLEDGE, A. Discourse and Power in a Multilingual World. Amsterdam: John Benjamins Publishing Company, 2005.

CAVALCANTI, M. C. Estudos sobre educação bilíngüe e escolarização em contextos de minorias lingüisticas no Brasil. In: D.E.L.T.A., São Paulo, v. 15, Special Issue, 1999. p.385-417. Available at: <http://www.scielo.br/scielo.php?pid=S010244501999000300015 \&script=sci_arttext $>$. Retrieved May 30, 2013.

CHOULIARAKI, L.; FAIRCLOUGH, N. Discourse in late modernity: rethinking Critical Discourse Analysis. Edinburgh: Edinburgh University Press, 1999.

DAMAZIO, M. F. M. Educação Escolar Inclusiva para Pessoas com Surdez. In: DAMAZIO, M. F. M. (ed.), Atendimento educacional especializado: pessoa com surdez. Brasília: MEC/SEESP, 2007. Available at: <http://portal.mec.gov.br/seesp/ arquivos/pdf/aee_da.pdf $>$. Retrieved May 30, 2013.

FAIRCLOUGH, N. Discourse and Social Change. Cambridge: Polity Press, 1992. FAIRCLOUGH, N. Critical Discourse Analysis: the critical study of language. London: Longman, 1995. 
FAIRCLOUGH, N. Analyzing Discourse: Textual Analysis for Social Research. London: Routledge, 2003.

FAIRCLOUGH, N. Semiotic aspects of social transformation and learning. In: ROGERS, R. An introduction to critical discourse analysis in education. New York: Routledge, 2011.

FAIRCLOUGH, N. Peripheral Vision: Discourse Analysis in Organization Studies: The Case for Critical Realism. In: Organization Studies, v.26, n. 6, , 2005. p. 915939. Available at: <http://oss.sagepub.com/content/26/6/915.abstract>. Retrieved May 30, 2013.

FARACO. C. A. Questóes de política de língua no Brasil: problemas e implicações. In: Educar em Revista, Curitiba, Universidade Federal de Paraná, v. 20, 2002. p. 1322. Avaible at: <http://www.redalyc.org/articulo.oa?id $=155018102003>$. Retrieved May 30, 2013.

FENEIS. Educação Inclusão. Available at: <http://www.feneis.org.br/page/ inclusao1.asp> . Retrieved May 5, 2013.

HABERMAS, J. Struggles for Recognition in the Democratic Constitutional State. In: GUTMAN, A. (Ed.) Multiculturalism. Princeton: Princeton University Press, 1994. p. 203-236.

HABERMAS, J. Equal Treatment of Cultures and the Limits of Postmodern Liberalism. In: The Journal of Political Philosophy, v. 13, n. 1, p. 1-28, 2005. Available at: <http://onlinelibrary.wiley.com/doi/10.1111/j.1467-9760.2005.00211.x/ abstract>. Retrieved May 30, 2013.

PICONI, Larissa Bassi Piconi. Formação de professores de língua inglesa numa abordagem sócio-histórico-cultural: a produção do currículo em questão (Masters Thesis in Language Studies). Londrina: The State University of Londrina, 2009.

OLIVEIRA, G. M. Brasileiro fala português: Monolinguismo e preconceito lingüístico. In: SILVA, F. L.; MOURA, H. M. M. O Direito à Fala: a questão do preconceitolingüistico. Florianópolis: Editora Insular, 2002.

OLIVEIRA, G. M. Prefácio. In: CALVET, L. As politicas linguisticas. São Paulo: Parábola Editorial: IPOL, 2007.

QUADROS, R. M. Linguistic Policies, Linguistic Planning, and Brazilian Sign Language in Brazil. In: Sign Language Studies, Washington: Gallaudet University Press. v. 12, n. 4, summer issue, 2012. p. 543-564. Avaiable at: <http://muse. jhu.edu/login?auth=0\&type=summary\&url=/journals/sign_language_studies/ v012/12.4.de-quadros.html>. Retrieved on May 30, 2013.

RAMALHO, V.; RESENDE, V. de M. Análise de discurso (para a) crítica: o texto como material de pesquisa. Campinas: Pontes, 2011. 
RESENDE, V.; RAMALHO, V. Análise de Discurso Crítica. São Paulo: Contexto, 2006.

ROGERS, R.(Ed.). An Introduction to Critical Discourse Analysis in Education. Mahwah: Lawrence Erlbaum, 2004.

Data de submissão: 04/09/2013. Data de aprovação: 28/04/2014. 
